\title{
The effect of tocilizumab on severe COVID-19 infection: Review of current evidence
}

Halil ibrahim YAKAR ${ }^{1}(I D)$
Ahmet Cemal
PAZARLI $^{\mathbf{2}}(\mathrm{ID})$
Handan INÖNÜ
KÖSEOĞLU $^{1}(\mathrm{ID})$
Asiye KANBAY $^{\mathbf{3}}$ (ID)

Cite this article as: Yakar Hi, Pazarlı AC, Inönü Köseoğlu $H$, Kanbay A. The effect of tocilizumab on severe COVID19 infection: review of current evidence. Tuberk Toraks 2021;69(1):74-83.

\section{Yazışma Adresi (Address for Correspondence)}

Dr. Halil ibrahim YAKAR

Gaziosmanpaşa Üniversitesi Araştırma ve Uygulama Hastanesi,

Göğüs Hastalıkları Anabilim Dalı,

TOKAT - TÜRKIYE

e-mail: halilibrahim.yakar@gop.edu.tr

CCopyright 2021 by Tuberculosis and Thorax. Available on-line at www.tuberktoraks.org.com
${ }^{1}$ Department of Chest Diseases, Gaziosmanpaşa University Research and Practice Hospital, Tokat, Turkey

${ }^{1}$ Gaziosmanpaşa Üniversitesi Araştırma ve Uygulama Hastanesi, Göğüs Hastalıkları Anabilim Dalı, Tokat, Türkiye

2 Department of Chest Diseases, Gaziosmanpaşa University Faculty of Medicine, Tokat, Turkey

${ }^{2}$ Gaziosmanpaşa Üniversitesi Tıp Fakültesi, Göğüs Hastalıkları Anabilim Dalı, Tokat, Türkiye

${ }^{3}$ Clinic of Chest Diseases, İstanbul Göztepe Training and Research Hospital, istanbul, Turkey

${ }^{3}$ istanbul Göztepe Eğitim ve Araştırma Hastanesi, Göğüs Hastalıkları Kliniği, istanbul, Türkiye

\section{ABSTRACT}

The effect of tocilizumab on severe COVID-19 infection: Review of current evidence

The COVID-19 outbreak that spread in December 2019 has caused the death of millions of people in a short time. Many studies published recently have shown that many cytokines (interleukin (IL) IL-1, IL-2, IL-6, TNF and IFN-) are significantly increased in COVID-19 patients with pneumonia, and especially IL-6 in combination with other cytokines has shown to be the main cause of the cytokine storm. Since IL-6 level is associated with clinical worsening in COVID-19 patients, anti-IL-6 therapy is seen as a promising treatment. Tocilizumab, a widely used IL-6 antagonist, was approved by the FDA in 2017 for Cytokine Storm Syndrome (CSS). Its addition to the treatment in COVID19 patients with increased blood IL-6 levels and oxygen saturation $<92 \%$ has been recommended due to bilateral widespread pulmonary infiltration. We summarized the studies on tocilizumab and COVID-19 disease published in the literature. In the light of current information, data on the mechanism of the action of tocilizumab, which is still widely used in COVID-19 patients, appropriate patient selection, effectiveness in treatment and side effects are presented.

Key words: COVID-19; cytokine storm syndrome; interleukin-6; interleukin-6 antagonist; Tocilizumab 


\section{Öz}

\section{Ağır COVID-19 enfeksiyonunda tosilizumab'ın etkinliği: Güncel çalışmaların derlemesi}

Aralık 2019'da başlayan COVID-19 salgını, kısa sürede milyonlarca insanın ölümüne yol açmıştır. Yakın zamanda yayınlanan çalışmalar, pnömoni ile seyreden COVID-19 hastalarında birçok sitokinin (IL-1, IL-2, IL-6, TNF ve IFN- $\gamma$ ) önemli ölçüde arttı̆̆ını ve özellikle Interlökin 6 (IL-6)'nın diğer sitokinlerle birlikte sitokin fırtınasının ana nedeni olduğunu göstermiştir. IL-6 düzeyi, COVID-19 hastalarında klinik kötüleşme ile ilişki bulunduğundan dolayı, anti-IL 6 tedavisi umut vaad eden tedavi olarak görülmektedir. Yaygın kullanılan IL-6 antagonisti olan Tosilizumab'ın 2017 yılında FDA tarafından Sitokin Fırtınası Sendromu için kullanımı onaylanmıştır. Kanda IL-6 düzeyi yükselmiş, akciğerde bilateral yaygın infiltrasyonu nedeniyle oksijen satürasyonu <\% 92 olan COVID-19 hastalarında tedaviye eklenmesi önerilmektedir. Bu çalışmada, 20 Ekim 2020'ye kadar literatürde yayınlanan Tosilizumab ve COVID-19 ile ilgili araştırmalar, meta-analizler ve randomize çalışmalar tarandı. Güncel bilgiler ışığında halen yaygın kullanımda olan Tosilizumab'ın COVID-19 hastalarında etki mekanizması, uygun hasta seçimi, tedavideki etkinliği ve yan etkileri hakkında veriler sunuldu.

Anahtar kelimeler: COVID-19; sitokin fırtınası sendromu; interlökin-6; interlökin-6 antagonisti; tosilizumab

\section{INTRODUCTION}

The COVID-19 (Coronavirus Disease-2019) outbreak started with the reporting of pneumonia of unknown cause in Wuhan City, China, in December 2019. It has spread all over the world in a very short time, causing the death of more than 1 million people and approximately 37 million people to become infected as of October 2020, according to WHO data (1). Due to high mortality and morbidity rates, researchers are in search of the best treatment for COVID-19 infection.

Interleukin 6 (IL-6) levels have been found to be higher in patients with severe COVID-19 infection (septic shock, multiorgan failure, high oxygen demand) compared to patients with mild and moderate COVID-19 disease $(2,3)$. Since IL-6 level has been found to be associated with clinical worsening in COVID-19 patients (4), anti-IL-6 therapy is considered as a promising treatment (5).

Tocilizumab, sarilumab and siltuximab are IL-6 antagonists with different pharmacological properties. Sarilumab has been approved only for rheumatoid arthritis (RA) and siltuximab for Castleman disease. However, tocilizumab has also been approved for the treatment of Juvenile Idiopathic Arthritis (JIA) and Giant Cell Arthritis (GCA) in addition to these diseases (6). Moreover, it was approved by the FDA in 2017 for the treatment of Cytokine Storm Syndrome (CSS) (7).

In this review, it was aimed to discuss the mechanism of the action of tocilizumab, which is still in widespread use in COVID-19 patients, appropriate patient selection, effectiveness in treatment and its side effects in the light of current evidence.

\section{Literature Search Method}

An electronic literature screening was conducted using Web of Science, PubMed and Google Scholar databases to find retrospective, observational and randomized controlled studies and meta-analyses published on tocilizumab and COVID-19. As Medical Subject Headings (MeSH) search items of "Coronavirus", "Tocilizumab", "COVID-19 and Tocilizumab", "Severe Acute Respiratory Syndrome", "SARS-CoV-2" were created. Reference lists of the studies were also checked to find greater number of research studies related to our search terms. Articles in languages other than English were excluded.

\section{The Pathogenesis and Importance of Cytokine Storm in COVID-19 Disease}

Cytokines, which are small proteins secreted by our immune system, have various functions such as communication between cells, regulation of innate and adaptive immunity, hematopoiesis, and repair of damaged tissues (8). Recent studies published have shown that many cytokines (IL-1, IL-2, IL-6, TNF, and IFN-) are significantly increased in COVID-19 patients with pneumonia, and IL-6 is the main cause of the cytokine storm together with other cytokines (9-10). As a trigger of inflammation, IL-6 is highly expressed in COVID-19 patients and induces differentiation of B lymphocytes, antibody production from B lymphocytes, as well as proliferation and differentiation of $T$ (11). B and T lymphocytes, which proliferate and differentiate in excess, enter the pulmonary circulation by causing cytokine storm, leading to lung alveolar damage and respiratory failure (12). It is thought that the definition of cytokine storm was first made in 1993, in graft versus host disease (13). Later, it was shown that cytokine storm due to the 
H5N1 virus caused multiple organ failure (14). In CSS, refractory hypotension, respiratory failure, coagulopathy, kidney and liver failure occur due to highly elevated immune activation of lymphocytes, macrophages or myeloid cells. It is thought that the increase in IL-6 and IFN gamma cytokines initiates the cytokine storm by increasing the differentiation of helper $\mathrm{T}$ ( $\mathrm{T}$ helper) lymphocytes (15). Since IL-6 is known as an important mediator of CSS, it is thought that targeted drugs that inhibit IL-6 can block cytokine storm (16).

\section{Possible Mechanism of the Action of Tocilizumab in COVID-19}

Mechanism of the action of tocilizumab in the treatment of COVID-19 is still unclear. Previous studies have shown that IL-6 is found in small amounts in fibroblasts, endothelial cells and tumor cells in addition to immune system cells such as B lymphocytes, $\mathrm{T}$ lymphocytes, macrophages, and monocytes (17). Normally, very low levels of IL-6 are synthesized rapidly due to reasons such as infection or injury, and its level in the blood increases. The higher the peak concentration of IL-6 in COVID-19 patients, the more severe the CSS. IL- 6 binds to its receptor IL-6R to form a complex, and this complex then binds to signal-converting glycoprotein 130 (gp-130) to initiate signal transduction and triggers gene expression (18). The IL-6 signaling pathway is mediated by two systems. The first pathway is mediated by the JAK/STAT tyrosine kinase system, while the other is mediated by the Ras/mitogen-activated protein kinase (MAPK)/ NF-KB-IL-6 pathway. Studies conducted to block signal pathways have been effective in various preclinical, chronic, and autoimmune disease models (19). Tocilizumab, a humanized anti-IL-6R monoclonal antibody, is thought to be effective for the treatment of cytokine storm in COVID-19 disease by inhibiting signaling pathways (Table 1).

Patient Selection and Drug Administration for Tocilizumab in the Treatment of COVID-19 Disease

Early recognition of CSS and starting treatment in COVID-19 patients is important to decrease mortality

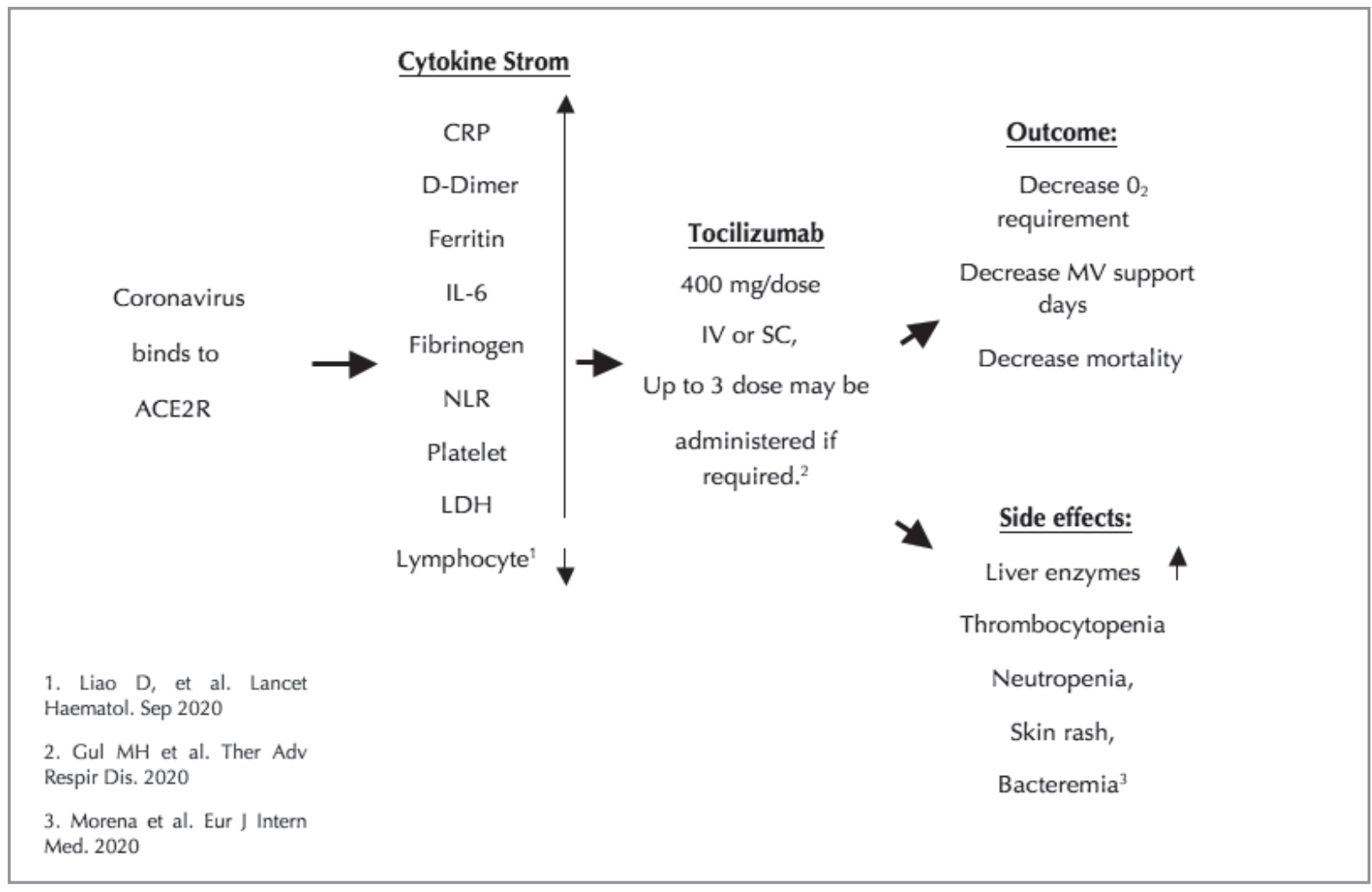

Table 1. The potential mechanism of cytokine storm and Tocilizumab as medical teatment of CSS on COVID-19.

IL: interleukin; ACE2R: ACE 2 Reseptors; CRP: C Reactive Protein; NLR: Neutrophil/Lymphocyte Ratio; LDH: Lactat Dehidrogenase Enzyme; $\mathrm{O}_{2}$ : Oxygen; MV: Mechanic Ventilation CSS: Cytokine Storm Sendrome. 
and morbidity. CSS should be considered if patients experience clinical worsening and have increased blood IL-6, ferritin, CRP, fibrinogen levels, neutrophil counts, and decreased lymphocyte and platelet counts $(20,21)$. Neutrophil/Lymphocyte (NLR) ratio has also been shown to be important in the diagnosis of CSS (21).

Tocilizumab, which has a monoclonal antibody structure that blocks IL-6 receptors, has been shown to be effective in CSS $(22,23)$. Therefore, tocilizumab has received FDA approval for CSS in addition to rheumatological indication (7). It is recommended to add tocilizumab to the treatment in patients with increased blood IL-6 levels and bilateral diffuse pulmonary infiltration (24).

Tocilizumab can be used alone or in combination with glucocorticoids in adults with severe or life-threatening CSS and in pediatric patients aged $>2$ years (7). The recommended doses of tocilizumab are $400 \mathrm{mg}$ in patients weighing 50-60 kg; $600 \mathrm{mg}$ for those weighing $60-85 \mathrm{~kg}$, and $800 \mathrm{mg}$ in patients weighing $>85 \mathrm{~kg}$ (25). Doses exceeding $800 \mathrm{mg}$ per infusion are not recommended $(7,24)$. It is administered intravenously or subcutanously. If there is no clinical improvement in signs and symptoms after the first dose, up to 3 additional doses may be administered at intervals of at least 8 hours. Infusion time should be at least one hour (7).

\section{Pharmaceutical Effectiveness of Tocilizumab in COVID-19 Disease}

Since March 2020, when the pandemic spread all over the world, many studies have been published investigating the effectiveness of tocilizumab in COVID-19 patients (Table 2). In a study conducted by $\mathrm{Xu}$ et al. in China, tocilizumab was given to respiratory failure patients with 17 severe and 4 critically ill COVID-19 disease in addition to routine treatment. All patients were discharged after tocilizumab treatment and no drug-related side effects were observed (26). In a study conducted by Sarhan et al. in Egypt, tocilizumab was given to patients with severe COVID19 disease. Improvement was observed in all laboratory parameters (IL 6, CRP, LDH, ferritin) of the patients and reduction of the length of stay in hospital and ICU, need for MV and mortality rate after double dose Tocilizumab treatment (27). Another prospective study included 85 patients with respiratory failure not requiring mechanical ventilation $(\mathrm{MV})$, better survival rates were obtained in the tocilizumab group compared to the control group $(p=0.004)$. While discharge rate was $92 \%$ in the group receiving tocilizumab, it was found to be $42.1 \%$ in the control group (28). Similarly, a multi-center retrospective study involving 544 patients, it was found that the need for invasive MV was significantly reduced in the tocilizumab group compared to the standard treatment group ( $p=0.020$ ) (29). Three doses of tocilizumab were administered to 100 patients with respiratory failure, and clinical improvement was observed at a rate of $58 \%$ on the 72 nd hour, and $77 \%$ of on the 10th day of tocilizumab treatment (30). MorenoGarcia et al. enrolled 171 patients and investigated the requirement for intensive care stay and intubation. They found lower intensive care unit stay and intubation in the tocilizumab group $(\mathrm{p}=0.005$ and $\mathrm{p}=$ 0.001 , respectively) (31). In a multi-center study including 1221 patients, the primary endpoints were 14-day and 30-day mortality rates. The mortality rates were found to be similar at the end of 14 days, whereas lower 30-day mortality rates were observed in the tocilizumab group $(p=0.52$, and $p<0.001$, respectively) (32). Somers et al. included 154 intubated COVID-19 patients, tocilizumab was found to reduce the risk of death (hazard of death) by $45 \%$ [hazard ratio $=0.55(95 \% \mathrm{Cl} 0.33,0.90)]$ (33). 1229 COVID-19 patients were divided into two groups according to their CRP levels. In the group with CRP> $150 \mathrm{mg} / \mathrm{L}$, tocilizumab significantly reduced the risk of death and number of admissions to intensive care units (aHR 0.34, $\mathrm{p}=0.005$; $\mathrm{aHR} 0.38, \mathrm{p}=0.011$ ). However, in the group with $C R P \leq 150 \mathrm{mg} / \mathrm{L}$, the mortality rate was similar (34). In the study conducted by Price et al. on 239 patients, tocilizumab was given to all patients considered to have CSS and stratified as those moderately and severely in need of oxygen therapy $\left(>3\right.$ It $\left.0_{2}\right)$. 14-day survival rates of the patients were $91 \%$ and $83 \%$ in moderately and severely ill patients, respectively, and $86 \%$ in all. Interestingly, unlike other studies, survival was found to be better in Afro-Americans and Hispanics than in the Caucasian race (35). Lastly, other group showed better survival in intubated COVID-19 patients who received tocilizumab (36). The effectiveness of anakinra, sarilumab, siltuximab and tocilizumab drugs used in cytokine storm were evaluated in a meta-analysis study. Seventy-one studies and a total of twenty two thousand patients were included. In prospective studies, tocilizumab was associated with improved 
Table 2. Characteristics of the studies about tosilizumab effectiveness on COVID-19 treatment

\begin{tabular}{|c|c|c|c|c|c|}
\hline Study & Study type & Population (N) & Treatment & Comparison & Main Findings \\
\hline Xu et al. (26) & $\begin{array}{l}\text { Multi-center } \\
\text { retrospective }\end{array}$ & $\begin{array}{c}\text { N: } 21 \\
\text { Severe: } 17 \\
\text { Critic: } 4\end{array}$ & $\begin{array}{c}\text { TCZ: Up to } 800 \\
\text { mg. In case of fever } \\
\text { within } \\
12 \mathrm{~h} \text {, single } \\
\text { additional dose }\end{array}$ & No comparison & $\begin{array}{l}\text { All patients discharged on } \\
\text { average } 15.1 \text { day after } \\
\text { TCZ. } 75.0 \% \text { of patients had } \\
\text { lower oxygen intake } 5 \text { days } \\
\text { after TCZ infusion. }\end{array}$ \\
\hline Sarhan et al. (27) & $\begin{array}{l}\text { Single-center } \\
\text { prospective }\end{array}$ & $N: 25$ & $\begin{array}{l}\text { N: } 25 \text { TCZ twice } \\
\text { doses (up to } 800 \\
\text { mg) }\end{array}$ & No comporison & $\begin{array}{c}\text { All patients showed } \\
\text { significantly lower median } \\
\text { IL-6, LDH, CRP, ferritin, TLC } \\
\text { at } p<0.001 \text { and D-Dimer at } \\
p=0.22 \text { than their baseline. } \\
\text { The number of patients who } \\
\text { required MV decreased from } \\
11 \text { to } 8 \text {. Only } 5 \text { patients died } \\
\text { after TCZ treatment. }\end{array}$ \\
\hline Capra et al. (28) & $\begin{array}{l}\text { Single-center, } \\
\text { retrospective }\end{array}$ & $\mathrm{N}: 85$ & $\begin{array}{l}\mathrm{N}: 62, \mathrm{TCZ}: 400- \\
800 \mathrm{mg}\end{array}$ & $\begin{array}{l}\text { N: } 23 \\
\text { Not receiving } \\
\text { TCZ }\end{array}$ & $\begin{array}{l}\text { TCZ group had greater } \\
\text { survival rate compared } \\
\text { to control }(p=0.004)\end{array}$ \\
\hline $\begin{array}{l}\text { Guaraldi et al. } \\
\text { (29) }\end{array}$ & $\begin{array}{l}\text { Multi-center } \\
\text { retrospective }\end{array}$ & $\mathrm{N}: 544$ & $\begin{array}{l}\text { N: } 179, \text { TCZ twice } \\
\text { doses (up to } 800 \\
\text { mg) }\end{array}$ & $\begin{array}{l}\text { N: } 365 \\
\text { Not receiving } \\
\quad \text { TCZ }\end{array}$ & $\begin{array}{l}\text { Tocilizumab reduced risk of } \\
\text { IMV or death }(p=0.020) \text {. }\end{array}$ \\
\hline Toniati et al. (30) & $\begin{array}{l}\text { Single-center } \\
\text { prospective }\end{array}$ & $\mathrm{N}: 100$ & $\begin{array}{c}\text { TCZ: Up to } 800 \\
\text { mg two infusions } \\
12 \mathrm{~h} \text { apart. A third } \\
\text { infusion, } 24 \mathrm{~h} \text { apart } \\
\text { from } \\
\text { if required. }\end{array}$ & No comparison & $\begin{array}{c}\text { At day } 10,77 \% \text { improved or } \\
\text { stabilized and } 23 \% \\
\text { worsened (of whom } 20 \% \\
\text { died). }\end{array}$ \\
\hline $\begin{array}{l}\text { Moreno-Garcia et } \\
\text { al. (31) }\end{array}$ & $\begin{array}{l}\text { Single-center } \\
\text { retrospective }\end{array}$ & $\begin{array}{l}\text { N: } 171 \\
\text { Non-ICU } \\
\text { patients with } \\
\text { COVID-19 }\end{array}$ & $\begin{array}{c}\mathrm{N}: 77, \mathrm{TCZ}: 400 \\
\mathrm{mg} \leq 75 \mathrm{~kg} \text { and } 600 \\
\mathrm{mg}>75 \mathrm{~kg} . \text { Up to } \\
3 \text { doses if partial } \\
\text { response }\end{array}$ & $\begin{array}{l}\mathrm{N}: 94 \\
\text { Not receiving } \\
\mathrm{TCZ}\end{array}$ & $\begin{array}{l}\text { Tocilizumab group had less } \\
\text { ICU admissions }(p=0.005) \\
\text { and less invasive ventilation } \\
\qquad(p=0.001) .\end{array}$ \\
\hline Somers et al. (33) & $\begin{array}{l}\text { Single-center } \\
\text { retrospective }\end{array}$ & $\begin{array}{c}\mathrm{N}: 154 \\
\text { severe } \\
\text { COVID-19 under } \\
\text { mechanical } \\
\text { ventilation }\end{array}$ & $\begin{array}{l}\mathrm{N}: 78, \mathrm{TCZ} \text { (up to } \\
800 \mathrm{mg} \text { ) }\end{array}$ & $\begin{array}{l}\text { N: } 76 \\
\text { Not receiving } \\
\text { TCZ }\end{array}$ & $\begin{array}{c}\text { TCZ associated with adjusted } \\
\text { ower hazard of death } \\
\text { (HR: 0.55) }\end{array}$ \\
\hline Perrone et al. (32) & $\begin{array}{l}\text { Multi-center, } \\
\text { open-label } \\
\text { trial, phase } 2 \\
\text { study }\end{array}$ & $\begin{array}{l}\text { N: } 1221 \\
\text { Hospitalized } \\
\text { patients with } \\
\text { COVID-19 }\end{array}$ & $\begin{array}{l}\text { TCZ up to } 800 \mathrm{mg}, \\
\text { (Second dose, if } \\
\text { required) }\end{array}$ & No comparison & $\begin{array}{c}\text { Mortality was } 18.4 \% \text { and } \\
22.4 \% \text { at } 14 \text { and } \\
30 \text { days in phase } 2 .\end{array}$ \\
\hline $\begin{array}{l}\text { Martinez-Sans et } \\
\text { al. (34) }\end{array}$ & $\begin{array}{l}\text { Multicenter } \\
\text { retrospective }\end{array}$ & $\begin{array}{l}\text { N: } 1229 \\
\text { Hospitalized } \\
\text { patients with } \\
\text { COVID-19 }\end{array}$ & $\begin{array}{c}\mathrm{N}: 260, \mathrm{TCZ}: \\
\text { median dose } 600 \\
\mathrm{mg}\end{array}$ & $\begin{array}{c}\text { N: } 969 \\
\text { Not receiving } \\
\text { TCZ }\end{array}$ & $\begin{array}{c}\text { TCZ group had higher risk of } \\
\text { death }(\mathrm{HR} 1.53, \mathrm{p}=0.001) \\
\text { ICU/death }(\mathrm{HR} 1.77, \\
\mathrm{p}<0.001) .\end{array}$ \\
\hline Price et al. (35) & $\begin{array}{l}\text { Single-center } \\
\text { prospective } \\
\text { nonrandomized } \\
\text { observational }\end{array}$ & $\begin{array}{l}\text { N: } 153 \\
\text { Hospitalized } \\
\text { patients with } \\
\text { COVID-19 }\end{array}$ & $\begin{array}{l}\text { TCZ: Up to } 800 \\
\text { mg; second dose if } \\
\text { required }\end{array}$ & No comparison & $\begin{array}{l}\text { Moderate and severe patients } \\
\text { survival were } \% 91 \text { and } \% 83 \\
\text { respectively at } 14 \text { days. }\end{array}$ \\
\hline Rossi et al. (36) & $\begin{array}{l}\text { Single-center } \\
\text { retrospective }\end{array}$ & $\begin{array}{c}\text { N: } 246 \\
\text { Patients with } \\
\text { severe } \\
\text { COVID-19 }\end{array}$ & $\begin{array}{l}\text { N: 106, TCZ: } 400 \\
\text { mg, single dose }\end{array}$ & $\begin{array}{c}\mathrm{N}: 140 \\
\text { Not receiving } \\
\mathrm{TCZ}\end{array}$ & $\begin{array}{l}\text { Tocilizumab group had fewer } \\
\text { mortality and IMV }(\mathrm{H}=0.49 \\
\qquad \mathrm{p}=0.005)\end{array}$ \\
\hline
\end{tabular}




\begin{tabular}{|c|c|c|c|c|c|}
\hline Study & Study type & Population (N) & Treatment & Comparison & Main Findings \\
\hline $\begin{array}{l}\text { Khan et al. } \\
(37)\end{array}$ & $\begin{array}{l}\text { Meta-analysis } \\
\text { study }\end{array}$ & $\begin{array}{l}71 \text { studies, } \\
\text { (6 random trials) } \\
\text { Total 22,058 } \\
\text { patients were } \\
\text { included }\end{array}$ & $\begin{array}{l}58 \text { studies were about } \\
\text { only TCZ treatment. } 13 \\
\text { studies were about } \\
\text { Anakinra (6), Sarilumab } \\
\text { (4), Siltuximab (1), } \\
\text { Anakinra and TCZ (1) } \\
\text { Sarilumab and TCZ (1). }\end{array}$ & No comparison & $\begin{array}{l}\text { TCZ was associated with a } \\
\text { lower relative risk of mortality in } \\
\text { prospective studies, but effects } \\
\text { were inconclusive for other } \\
\text { outcomes. Current evidence for } \\
\text { the efficacy of anakinra, } \\
\text { siltuximab or sarilumab in } \\
\text { COVID-19 is insufficient. }\end{array}$ \\
\hline $\begin{array}{l}\text { Gupta et al. } \\
(38)\end{array}$ & $\begin{array}{l}\text { Multi-center } \\
\text { cohort study }\end{array}$ & $\begin{array}{l}\text { N: } 3924 \\
\text { Patients with } \\
\text { severe } \\
\text { COVID-19 }\end{array}$ & $\begin{array}{l}\mathrm{N}: 433(11 \%) \text { patients } \\
\text { received TCZ in the } \\
\text { first } 2 \text { days of ICU } \\
\text { admission. }\end{array}$ & $\begin{array}{l}\mathrm{N}: 3491 \text { did not } \\
\text { receive TCZ } \\
\text { within } 2 \text { days of } \\
\mathrm{ICU} \text { admission }\end{array}$ & $\begin{array}{l}\text { The } 1544 \text { patients who died } \\
\text { included } 125 \text { of the } 433 \\
\text { patients }(28.9 \%) \text { treated with } \\
\text { TCZ and } 1419 \text { of the } 3491 \\
\text { patients }(40.6 \% \text { ) not treated } \\
\text { with TCZ (unadjusted HR, } \\
0.64 ; 95 \% \mathrm{Cl}, 0.54-0.77) \text {. }\end{array}$ \\
\hline $\begin{array}{l}\text { Salama et al. } \\
(39)\end{array}$ & $\begin{array}{l}\text { Randomized, } \\
\text { placebo- } \\
\text { controlled trial }\end{array}$ & $\begin{array}{l}\text { N: } 389 \\
\text { Hospitalized } \\
\text { Patients with } \\
\text { COVID-19 } \\
\text { randomized. }\end{array}$ & $\begin{array}{l}\text { N: } 249 \text { patients in the } \\
\text { TCZ group }\end{array}$ & $\begin{array}{l}\mathrm{N}: 128 \text { patients } \\
\text { in the placebo } \\
\text { group }\end{array}$ & $\begin{array}{c}\text { Percentage of patients who had } \\
\text { received MV or who had died } \\
\text { by day } 28 \text { was } 12.0 \% \text { in the } \\
\text { TCZ group and } 19.3 \% \text { in the } \\
\text { placebo group (HR for MV or } \\
\text { death, } 0.56 ; \mathrm{p}=0.04 \text { by log- } \\
\text { rank test). }\end{array}$ \\
\hline $\begin{array}{l}\text { Rajendram et } \\
\text { al. (40) }\end{array}$ & $\begin{array}{l}\text { Propensity } \\
\text { Matched } \\
\text { Analysis Study }\end{array}$ & $\begin{array}{l}\text { N: } 444 \\
\text { Patients with } \\
\text { severe } \\
\text { COVID-19 }\end{array}$ & $\begin{array}{l}102 \text { patients ( } 23 \%) \\
\text { received TCZ. } 82 \\
\text { patients in each arm } \\
\text { were matched } \\
\text { between two group. }\end{array}$ & $\begin{array}{l}342 \text { patients } \\
(77 \%) \text { did not } \\
\text { receive TCZ }\end{array}$ & $\begin{array}{l}\text { TCZ use was associated with a } \\
\text { significant decrease in ICU } \\
\text { mortality at } 28 \text { days in } \\
\text { critically ill coronavirus disease } \\
2019 \text { patients with severe } \\
\text { hypoxemic respiratory failure }\end{array}$ \\
\hline $\begin{array}{l}\text { Kow et al. } \\
(41)\end{array}$ & $\begin{array}{l}\text { Meta-analysis } \\
\text { study of } \\
\text { randomized } \\
\text { controlled trials }\end{array}$ & $\begin{array}{l}\text { Six RCTs were } \\
\text { included }\end{array}$ & $\begin{array}{l}\text { Two trials with an } \\
\text { overall low risk of bias } \\
\text { and four trials had } \\
\text { some concerns } \\
\text { regarding the overall } \\
\text { risk of bias. }\end{array}$ & No comparison & $\begin{array}{l}\text { Despite no clear mortality } \\
\text { benefits in hospitalized patients } \\
\text { with COVID-19, tocilizumab } \\
\text { appears to reduce the } \\
\text { likelihood of progression to } \\
\text { mechanical ventilation. }\end{array}$ \\
\hline $\begin{array}{l}\text { Campochiaro } \\
\text { et al. }(42)\end{array}$ & $\begin{array}{l}\text { Single-center, } \\
\text { prospective }\end{array}$ & $\mathrm{N}: 65$ & $\begin{array}{l}\text { N: } 32, \text { TCZ: Single } \\
\text { dose } 400 \mathrm{mg} \\
\text { (Second dose, if } \\
\text { required) }\end{array}$ & $\begin{array}{l}\text { N: } 33 \\
\text { Not receiving } \\
\text { TCZ }\end{array}$ & $\begin{array}{l}\text { Discharge from hospital and } \\
\text { clinical improvment similar }(\mathrm{p}= \\
0.32 ; \mathrm{p}=0.61 \text {, respectively). }\end{array}$ \\
\hline $\begin{array}{l}\text { Colaneri et al. } \\
\text { (43) }\end{array}$ & $\begin{array}{l}\text { Single-center } \\
\text { retrospective }\end{array}$ & $\begin{array}{l}\mathrm{N}: 112 \\
\text { Hospitalized } \\
\text { patients with } \\
\text { COVID-19 }\end{array}$ & $\begin{array}{l}\mathrm{N}: 21, \mathrm{TCZ} \text { : up to } 800 \\
\text { mg per dose, } \\
\text { repeated after } 12 \mathrm{~h} \text { if } \\
\text { no side effects }\end{array}$ & $\begin{array}{l}\text { N: } 91 \\
\text { Not receiving } \\
\text { TCZ }\end{array}$ & $\begin{array}{l}\text { TCZ group had similar ICU } \\
\text { admission }(p=0.22) \text { and } 7 \text {-day } \\
\text { mortality }(p=0.84) \text { compared } \\
\text { with standard group. }\end{array}$ \\
\hline Ip et al. (44) & $\begin{array}{l}\text { Multi-center, } \\
\text { retrospective, } \\
\text { observational }\end{array}$ & $\begin{array}{c}\text { N: } 547 \\
\text { ICU patients } \\
\text { with COVID-19 }\end{array}$ & $\begin{array}{c}\mathrm{N}: 134, \mathrm{TCZ}: 400 \mathrm{mg} \\
(96 \%), \text { followed by } \\
800 \mathrm{mg}(1 \%), 8 \mathrm{mg} / \mathrm{kg} \\
(1 \%), 4 \mathrm{mg} / \mathrm{kg}(1 \%), \\
\text { and missing dosing } \\
(1 \%) .\end{array}$ & $\begin{array}{l}\text { N: } 413 \\
\text { Not receiving } \\
\text { TCZ }\end{array}$ & $\begin{array}{l}\text { TCZ group associated with } \\
\text { greater survival }(\mathrm{HR}=0.76) .30 \\
\text { day mortality with and without } \\
\text { TCZ of } 46 \% \text { versus } 56 \% \text {. }\end{array}$ \\
\hline $\begin{array}{l}\text { Stone et al. } \\
(45)\end{array}$ & $\begin{array}{l}\text { Randomized, } \\
\text { double-blind, } \\
\text { placebo- } \\
\text { controlled trial }\end{array}$ & $\begin{array}{l}\text { N: } 243 \\
\text { Patients with } \\
\text { severe } \\
\text { COVID-19 }\end{array}$ & $\begin{array}{c}\mathrm{N}: 161, \mathrm{TCZ} \text { up to } 800 \\
\mathrm{mg}\end{array}$ & $\begin{array}{c}\text { N: } 82 \\
\text { Placebo group }\end{array}$ & $\begin{array}{l}\text { TCZ group had similar } \\
\text { worsening of disease (\%18.0, } \\
\% 14.9, \mathrm{p}=0.73 \text { ) and median } \\
\text { time to discontinuation of } \\
\text { supplemental } 02 \text { terapy } \\
\text { compared with placebo group } \\
\text { (5.0 days, } 4.9 \text { days, } \mathrm{p}=0.69) \text {. }\end{array}$ \\
\hline
\end{tabular}


survival (HR 0.83, 95\% Cl 0.72-0.96), but conclusive benefit was not demonstrated for other drugs. However, in the conclusion of this meta-analysis study, it was emphasized that the fact that exact benefits of anakinra, siltuximab and sarilumab could not be demonstrated may be due to the insufficient evidence available (37). A multi-center cohort study conducted by Gupta et al. on 3924 critically ill patients with COVID-19 showed that early administration of tocilizumab was associated with prolonged survival. Patients treated with tocilizumab had a lower risk of death compared to those not treated with tocilizumab (HR, $0.71 ; 95 \% \mathrm{Cl}, 0.56-0.92)$. The estimated thirty day mortality in the tocilizumab and non-tocilizumab group were found $27.5 \%$ and $37.1 \%$ respectively (38). In a randomised study conducted by Salama et al. on the modified intention-totreat population included 249 patients in the tocilizumab group and 128 patients in the placebo group. The cumulative percentage of patients who had received MV or died by day 28 was lower in the tocilizumab group than the placebo group (12.0\%; $19.3 \% ; p=0.04)$. However, death from any cause by day 28 was similar between the two groups in this study $(10.4 \% ; 8.6 \%$, respectively) (39). In a propensity match analysis study, 82 patients in each arm were matched with patient groups who received tocilizumab and did not receive tocilizumab. ICU mortality was lower in the tocilizumab group $(23.2 \%$ vs $37.8 \%$ ) with more ICU, hospital, and vasoactive free days at day 28 compared with those who did not receive tocilizumab (40). In a meta-analysis study including six randomized controlled trials, the overall effect of tocilizumab on the risk of mortality was summarized among patients with COVID-19. Despite no benefits in the mortality of hospitalized patients with COVID-19, tocilizumab appears to reduce the likelihood of progression to $M V$ in this study $(\mathrm{H}=$ $0.62 ; n=749)(41)$.

In contrast, tocilizumab did not show the expected benefit in some recent studies (42-45). In a prospective study conducted by Campochiaro et al. on 65 COVID-19 patients, the patients were divided into two groups as those receiving standard therapy or tocilizumab. Although survival in the first 28 days was better in the group receiving tocilizumab, discharge rates and clinical improvement rates were similar $(p=0.15, p=0.32, p=0.61$, respectively) (42). In the same line, Colaneri et al. did not found any difference in tocilizumab and standart therapy group in terms of need for intensive care and 7-day survival $(p=0.84, p=0.22$, respectively) (43). Ip et al. retrospectively investigated 547 COVID-19 patients hospitalized in intensive care units. They found survival similar in the tocilizumab and the control group (44). A total of 243 patients who did not need MV were included in the randomized controlled double-blind study. Tocilizumab was given to one group in addition to the standard treatment, and the other group received only placebo. After 14 days, COVID-19 disease worsened in comparable percentages of the patients in both groups $(18 \%$ and $14.9 \%$, respectively; $\mathrm{p}=0.73$ ). In addition, the median time required to get rid of the need for oxygen support was similar in both groups (5.0 days, 4.9 days, respectively; $p=$ 0.69) (45). However, Leaf et al. criticized this study. They signified that this study was severely underpowered because in the placebo group, the percentage of patients with a primary outcome event (i.e., intubation or death) was $12.5 \%$, far lower than the anticipated $30 \%$. So, Leaf et al. emphasized that these results should not be extrapolated to other populations of patients with COVID-19, particularly the critically ill (46).

Tocilizumab has been found to be effective in many studies, but not in other studies which may be related to variables such as the methodology of the studies, the disease severity, heterogeneity in critical methodological issues, late initiation of tocilizumab treatment, comorbidities and age of the patients included in the study. Timing of tocilizumab treatment is very important. It should be evaluated on mild-moderate disease in high-risk patients before any signs of pneumonia. It is recommended that tocilizumab treatment should be initiated within the first two days of CSS since irreversible organ injury can occur after cytokine storm is initiated (38). Findings from other studies emphasized early use of tocilizumab in those with severe disease $(29,35)$. During the early infection period (viral load), tocilizumab has no benefit beacuse CSS is not initiated. In additon, adverse effect and secondary infection risk may increase in the early period.

\section{Drug Safety and Side Effects of Tocilizumab}

It has been shown that tocilizumab can be used safely in many autoimmune diseases such as Takayasu arteritis and giant cell arteritis (47-48), but since these studies have been conducted in the restricted patient groups, study data related to a large population are 
lacking. Possible side effects of tocilizumab due to its long-term use in autoimmune patients include occurrence of opportunistic infection due to its anti-inflammatory activity (pneumonia, invasive aspergillosis, urinary tract infection, diverticulitis, cystitis), gastrointestinal perforation (especially in concurrent non-steroidal anti-inflammatory users), elevated liver enzymes, infusion-related hypertension, headache, and allergic skin reactions $(26,49)$. However, since short-term use is planned in COVID-19 patients, it is not clear whether the side effects that occur in long-term use also develop in its short-term use.

As expected, serum IL-6 level may increase after tocilizumab administration in COVID-19 patients due to the blockage of receptor IL-6R (50). Although it is recommended to use tocilizumab carefully in those with absolute neutrophil count below $<2 \times 10^{9} / \mathrm{L}$, its use in those with neutrophil counts below $0.5 \times 10^{9} / \mathrm{L}$ is not recommended. In addition, its use is not recommended in patients with platelet levels $<50 \times 10^{3} / \mu \mathrm{L}$. Treatment is recommended to be discontinued in patients whose liver AST/ALT level reaches 5 times the normal (26).

In a study by Campochiaro et al. regarding side effects of tocilizumab in COVID-19 patients, the incidence of adverse events was found to be similar to the group receiving standard therapy $(25 \%, 27 \%$, respectively, $\mathrm{p}=0.99)(42)$. In the study conducted by Salama et al., serious adverse events occurred similar between tocilizumab and placebo group (38 of 250 patients $(15.2 \%)$ in the tocilizumab group and 25 of 127 patients (19.7\%) in the placebo group) (39). Similary, retropective studies revealed no serious side effects related with tocilizumab treatment (43-44).

On the other hand, development of new infection was found to be significantly higher in the group that received tocilizumab compared to the control group $(13 \%$, and $4 \%$, respectively: $p<0.001)(29)$. In another study including 100 patients, two patients died from septic shock and one from gastrointestinal perforation (30). In a propensity-match analysis study, rates of secondary infections were higher in the tocilizumab cohort ( $26.5 \%$ vs $15.8 \%$ ) before matching. However, after matching, there was no difference in rates of secondary infection $(25.6 \%$ vs $25.6 \%)(40)$.

Moreover, tocilizumab may increase liver enzymes level, thrombocytopenia, neutropenia, skin rash and bacteremia $(35,51)$. However, neutropenia was also found in $6-8 \%$ of COVID-19 patients who did not receive tocilizumab (52-53). Due to these different data, studies with larger participation are required to evaluate side effects of tocilizumab as neutropenia and bacteremia. In addition, since high transaminase levels may be associated with the progression of COVID-19 disease and CSS in patients receiving tocilizumab, randomized studies are needed so as to be able to claim the presence of tocilizumab-induced hepatotoxicity in these patients.

\section{The Use of Tocilizumab in Special Populations}

It has been stated that tocilizumab may have a negative effect on the immune development of the fetus in pregnant women. Caution is recommended in patients over 65 years of age, as it may increase the risk of severe infections. Caution should be exercised in terms of neutropenia and thrombocytopenia. It can be used safely without dose adjustment in mild and moderate renal failure (creatine clearance $>30 \mathrm{~mL} /$ min) (26). There are insufficient data for its use in liver failure, but if liver enzymes triple the upper limit of normal due to tocilizumab treatment, it is recommended to wait for these levels to drop down to normal levels (54).

\section{CONCLUSION}

Despite significant advances made worldwide in the fight against the COVID-19 pandemic; it is still unclear why some people experience cytokine storm and what the treatment strategy is in these patients. One of the key cytokines in CSS associated with COVID-19 infection is IL-6. Tocilizumab can play an active role in the treatment of the CSS caused by COVID-19 by blocking inflammation via binding IL-6R. However, there is still not enough evidence regarding the clinical efficacy and safety of tocilizumab in COVID-19 patients. Further randomised controlled studies with big sample size are urgently warranted to elucidate the role of tocilizumab in COVID-19 patients.

\section{REFERENCES}

1. World Health Organization (WHO). Coronavirus Disease (COVID-19) Dashboard. Accessed date: 15 Nov 2020. Available from: https://covid19.who.int

2. Zhou F, Yu T, Du R, Fan G, Liu Y, Liu Z, et al. Clinical course and risk factors for mortality of adult inpatients with COVID-19 in Wuhan, China: a retrospective cohort study. Lancet 2020; 395: 1054-62. 
3. Ruan Q, Yang K, Wang W, Jiang L, Song J. Clinical predictors of mortality due to COVID-19 based on an analysis of data of 150 patients from Wuhan, China. Intensive Care Med 2020; 46: 846-8.

4. Coomes EA, Haghbayan H. Interleukin-6 in Covid-19: A systematic review and meta-analysis. Rev Med Virol 2020; 30(6): 1-9.

5. Cortegiani A, Ippolito M, Ingoglia G, Einav S. Chloroquine for COVID-19: rationale, facts, hopes. Crit Care 2020; 8; 24(1): 210.

6. Tufan A, Avanoğlu Güler A, Matucci-Cerinic M. COVID19, immune system response, hyperinflammation and repurposing antirheumatic drugs. Turk I Med Sci 2020; $21 ; 50(S I-1): 620-32$.

7. The U.S. Food and Drug Administration. Information for ACTEMRA ${ }^{\circledR}$. Accessed date: 15 Nov 2020. Available from: https://www.accessdata.fda.gov/drugsatfda_docs/ label/2017/125276s114lbl.pdf.

8. Tisoncik JR, Korth MI, Simmons CP, Farrar J, Martin TR, Katze $M G$, et al. Into the eye of the cytokine storm. Microbiol Mol Biol Rev 2012; 76(1): 16-32.

9. Huang C, Wang Y, Li X, Ren L, Zhao J, Hu Y, et al. Clinical features of patients infected with 2019 novel coronavirus in Wuhan, China. Lancet 2020; 395(10223): 497-506.

10. Liu J, Li S, Liu J, Liang B, Wang X, Wang H, et al. Longitudinal characteristics of lymphocyte responses and cytokine profiles in the peripheral blood of SARS-CoV-2 infected patients. EBioMed 2020; 55: 102763.

11. Zhai H, Liu Y, Wang Y, Li X, Li T. The pathogen distribution and its influence on inflammatory factors in old patients with heart failure complicated with pulmonary infection. Tianjin Med J 2018; 46(9): 952-5.

12. Yonggang $Z$, Binqing $F$, Xiaohu $Z$, Dongsheng $W$, Changcheng Z, Yingjie $Q$, et al. Pathogenic T-cells and inflammatory monocytes incite inflammatory storms in severe COVID-19 patients. Nat Sci Rev 2020; 7(6): 9981002.

13. Ferrara JL, Abhyankar S, Gilliland DG. Cytokine storm of graftversus-host disease: a critical efector role for interleukin-1. Transplant Proc 1993; 25(1 Pt 2): 1216-17.

14. De Jong MD, Simmons CP, Thanh TT, Hien VM, Smith GJ, Chau $T N$, et al. Fatal outcome of human infuenza $A$ (H5N1) is associated with high viral load and hypercytokinemia. Nat Med 2006; 12(10): 1203-7.

15. Teachey DT, Lacey SF, Shaw PA, Melenhorst JJ, Maude SL, Frey $N$, et al. Identifcation of predictive biomarkers for cytokine release syndrome after chimeric antigen receptor T-cell therapy for acute lymphoblastic leukemia. Cancer Discov 2016; 6(6): 664-79.

16. Tanaka T, Narazaki M, Kishimoto T. Immunotherapeutic implications of IL-6 blockade for cytokine storm. Immunotherapy 2016; 8(8): 959-70.
17. Jones $S A$, Jenkins BJ. Recent insights into targeting the IL-6 cytokine family in infammatory diseases and cancer. Nat Rev Immunol 2018; 18(12): 773-89.

18. Braun GS, Nagayama Y, Maruta Y, Heymann F, van Roeyen $C R$, Klinkhammer $B M$, et al. IL-6 trans-signaling drives murine crescentic GN. Am Soc Nephrol 2016; 27(1): 132-42.

19. Rose-John S. The soluble Interleukin 6 receptor: advanced therapeutic options in inflammation. Clin Pharmacol Ther 2017; 102(4): 591-8.

20. Zhu Z, Cai T, Fan L, Lou K, Hua X, Huang Z, et al. Clinical value of immune-inflammatory parameters to assess the severity of coronavirus disease 2019. Int I Infect Dis 2020; 95: 332-9.

21. Henry BM, de Oliveira MHS, Benoit S, Plebani M, Lippi G. Hematologic, biochemical and immune biomarker abnormalities associated with severe illness and mortality in coronavirus disease 2019 (COVID-19): a meta-analysis. Clin Chem Lab Med 2020: 25; 58(7): 1021-8.

22. Fitzgerald JC, Weiss SL, Maude SL, Barrett DM, Lacey SF, Melenhorst JJ, et al. Cytokine release syndrome after chimeric antigen receptor $T$ cell therapy for acute lymphoblastic leukemia. Crit Care Med 2017; 45: 124-31.

23. Maude SL, Laetsch TW, Buechner J, Rives S, Boyer M, Bittencourt $H$, et al. Tisagenlecleucel in children and young adults with B-cell lymphoblastic leukemia. N Engl J Med 2018; 378(5): 439-48.

24. Wei P-F. Diagnosis and treatment protocol for novel coronavirus pneumonia (Trial Version 7). Chin Med J 2020; 133: 1087-95.

25. Gul MH, Htun ZM, Shaukat N, Imran M, Khan A. Potential specific therapies in COVID-19. Ther Adv Respir Dis 2020; 14: 1753466620926853.

26. Xu X, Han M, Li T, Sun W, Wang D, Fu B, et al. Effective treatment of severe COVID-19 patients with tocilizumab. Proc Natl Acad Sci USA 2020; 19; 117(20): 10970-5.

27. Sarhan RM, Madney YM, Abou Warda AE, Boshra MS. Therapeutic efficacy, mechanical ventilation, length of hospital stay, and mortality rate in severe COVID-19 patients treated with tocilizumab. Int J Clin Pract 2021; 6: 14079.

28. Capra R, De Rossi N, Mattioli F, Romanelli G, Scarpazza C, Sormani MP, et al. Impact of low dose tocilizumab on mortality rate in patients with COVID-19 related pneumonia. Eur J Intern Med 2020; 176: 31-35.

29. Guaraldi G, Meschiari M, Cozzi-Lepri A, Milic J, Tonelli R, Menozzi $M$, et al. Tocilizumab in patients with severe COVID-19: a retrospective cohort study. Lancet Rheumatol 2020; 12; 8: 474-84.

30. Toniati P, Piva S, Cattalini M, Garrafa E, Regola F, Castelli F, et al. Tocilizumab for the treatment of severe COVID-19 pneumonia with hyperinflammatory syndrome and acute respiratory failure: a single-center study of 100 patients in Brescia, Italy. Autoimmun Rev 2020; 19: 102568. 
31. Moreno Garcia E, Rico Caballero V, Albiach L, Aguero D, Ambrosioni l, et al. Tocilizumab is associated with reduction of the risk of ICU admission and mortality in patients with SARS-CoV-2 infection. medRxiv 2020; 20113738.

32. Perrone F, Piccirillo MC, Ascierto PA, Salvarani C, Parrella $R$, Marata AM, et al. Tocilizumab for patients with COVID19 pneumonia. The single-arm TOCIVID-19 prospective trial. J Transl Med 2020; 18(1): 405.

33. Somers EC, Eschenauer GA, Troost JP, Golob IL, Gandhi $T N$, et al. Tocilizumab for treatment of mechanically ventilated patients with COVID-19. Clin Infect Dis 2020; ciaa954.

34. Martínez-Sanz J, Muriel A, Ron R, Herrera S, Pérez-Molina $J A$, et al. Effects of tocilizumab on mortality in hospitalized patients with COVID-19: a multicentre cohort study. Clin Microbiol Infect 2020; 27(2): 238-43.

35. Price CC, Altice FL, Shyr Y, Koff A, Pischel L, Goshua G, et al. Tocilizumab treatment for cytokine release syndrome in hospitalized patients with coronavirus disease 2019: survival and clinical outcomes. Chest 2020; 158(4): 1397-408.

36. Rossi B, Nguyen LS, Zimmermann P, Boucenna F, Dubret $L$, Baucher $L$, et al. Effect of tocilizumab in hospitalized patients with severe COVID-19 pneumonia: a case-control cohort study. Pharmaceuticals (Basel) 2020; 17; 13(10): 317

37. Khan FA, Stewart I, Fabbri L, Moss S, Robinson K, Smyth $A R$, et al. Systematic review and meta-analysis of anakinra, sarilumab, siltuximab and tocilizumab for COVID-19. Thorax medRxiv 2020; 20076612.

38. Gupta S, Wang W, Hayek SS, Chan L, Mathews KS, Melamed ML, et al. Association between early treatment with tocilizumab and mortality among critically ill patients with COVID-19. JAMA Intern Med 2021; 181(1): 41-51.

39. Salama C, Han J, Yau L, Reiss WG, Kramer B, Neidhart JD et al. Tocilizumab in patients hospitalized with Covid-19 pneumonia. N Engl J Med 2021; 384(1): 20-30.

40. Rajendram P, Sacha GL, Mehkri O, Wang X, Han X, Vachharajani $V$, Duggal A. Tocilizumab in coronavirus disease 2019-related critical illness: a propensity matched analysis. Crit Care Explor 2021; 3(1): 0327.

41. Kow CS, Hasan SS. The effect of tocilizumab on mortality in hospitalized patients with COVID-19: a meta-analysis of randomized controlled trials. Eur J Clin Pharmacol 2021; 2: 1-6.

42. Campochiaro C, Della-Torre E, Cavalli G, De Luca G, Ripa $M$, Boffini $N$, et al. Efficacy and safety of tocilizumab in severe COVID-19 patients: a single-center retrospective cohort study. Eur J Intern Med 2020; 76: 43-9.
43. Colaneri M, Bogliolo L, Valsecchi P, Sacchi P, Zuccaro V, Brandolino $F$, et al. Tocilizumab for treatment of severe COVID-19 patients: preliminary results from SMAtteo COvid19 REgistry (SMACORE). Microorganisms 2020; 8: 695.

44. Ip A, Berry DA, Hansen E, Goy AH, Pecora AL, Sinclaire $B A$, et al. Hydroxychloroquine and tocilizumab therapy in COVID-19 patients-an observational study. PLoS One 2020; 13; 15(8): 0237693 .

45. Stone $J H$, Frigault MJ, Serling-Boyd NJ, Fernandes $A D$, Harvey L, Foulkes AS, et al. Efficacy of tocilizumab in patients hospitalized with Covid-19. N Engl I Med 2020; 383: 2333-44.

46. Stone JH, Horick NK, Healy BC. Tocilizumab in Covid-19 Reply. N Engl J Med 2021; 384(1): 87.

47. Nakaoka Y, Isobe M, Takei S, Tanaka Y, Ishii T, Yokota S, et al. Eficacy and safety of tocilizumab in patients with refractory Takayasu arteritis: results from a randomised, double-blind, placebo-controlled, phase 3 trial in Japan (the TAKT study). Ann Rheum Dis 2018; 77(3): 348-54.

48. Samson $M$, Devilliers $H$, Ly KH, Maurier F, Bienvenu $B$, Terrier B, et al. Tocilizumab as an addon therapy to glucocorticoids during the frst 3 months of treatment of giant cell arteritis: a prospective study. Eur I Intern Med 2018; 57: $96-104$

49. Helleberg M, Steensen M, Arendrup MC. Invasive aspergillosis in patients with severe COVID-19 pneumonia. Clin Microbiol Infect 2021; 27(1): 147-8.

50. Nishimoto N, Terao K, Mima T, Nakahara H, Takagi N, Kakehi T. Mechanisms and pathologic significances in increase in serum interleukin-6 (IL-6) and soluble IL-6 receptor after administration of an anti-IL-6 receptor antibody, tocilizumab, in patients with rheumatoid arthritis and Castleman disease. Blood 2008; 15; 112(10): 395964.

51. Morena V, Milazzo L, Oreni L, Bestetti G, Fossali T, Bassoli C, et al. Off-label use of tocilizumab for the treatment of SARS-CoV-2 pneumonia in Milan, Italy. Eur I Intern Med 2020; 76: 36-42.

52. Feng Y, Ling Y, Bai T, Xie Y, Huang J, Li J, et al. COVID-19 with different severities: a multicenter study of clinical features. Am I Respir Crit Care Med 2020; 201(11): 1380-8.

53. Goyal P, Choi JJ, Pinheiro LC, Schenck EJ, Chen R, Jabri A, et al. Clinical characteristics of Covid-19 in New York City. N Engl J Med 2020; 11; 382(24): 2372-4.

54. Barlow A, Landolf KM, Barlow B, Yeung SYA, Heavner J, Claassen $C W$, et al. Review of emerging pharmacotherapy for the treatment of coronavirus disease 2019. Pharmacother 2020; 40(5): 416-37. 